\title{
Bone Hydatidosis
}

\author{
Jaime Paulos
}

\section{Abstract}

Bone hydatidosis is a bone infection due to equinococosis granulosus. It is a rare condition, similar to a multilocular osteolytic lesion. It occurs in endemic regions with that infection.

\section{Keywords}

Bone hydatidosis - Equinococosis infection

Bone hydatidosis is a rare condition and also not very frequent among all the cases of hydatidosis (estimated at 0,5-3\% of the cases). It is a zoonosis whose aethiology is the equinococosis granulosus in the larval stage. In Chile [1], the cases come from the cattle in the southern region. The spine,

long bones and pelvis are the most frequent bone locations. The conventional $\mathrm{Rx}$ shows an osteolytic multilocular lesion. Inmuno diagnosis is useful. Its treatment combines surgery [2] together with antiparasitic drugs (albendazol, mebendazol).

\section{References}

1. Oscar T, Vidal A, Bellolio E, Roa JC. Bone hydatidosis, report of five cases. Rev Med Chile 2010;138: 1414-1421. https://doi.org/10. 4067/SOO34-98872010001200011

2. Gorun N. Necessary hip disarticulation in extended echinococosis of the femur. Rev Chir Orthop Reparatrice Appar Mot. 1992;78:255-7. www.higiene.edu.uy/parasite/teo09/hidatid.pdf 